\title{
Beneficial using of EDTA to reduce cadmium toxicity and to improve the physiological and biochemical profiles of catfish (Clarias gariepinus)
}

\author{
Adel, M. Shalaby ${ }^{1}$, Ashraf. A. Ramadan ${ }^{2}$, Mostafa A. El Gammal ${ }^{3}$, El-Sadiq M \\ El Aganif ${ }^{4}$ and Mohamed S. M. Ebrahim ${ }^{5}$
}

1-Hatchary and Fish Physiology Department 2- Fish Genetics Department, 3-Fish limnology Departement, 5- Fish Ecology Department Central Laboratory for Aquaculture Research, Abbassa, Abo- Hammad, Sharkia, Egypt. 4- Aquaculture Department - Faculty of Agriculture, Trapoiils University, libya.

\begin{abstract}
EDTA form metal-EDTA complexes which have its effectiveness in mobilizing of the contaminant metal ions, especially cadmium. This work was carried out to investigate the effect of the ion - exchanging (chelating) agent EDTA on cadmium $(\mathrm{Cd})$ toxicity and its impact on haematological and biochemical changes in catfish (Clarias gariepinu)). The fish (160-180g ) were exposed to $12 \mathrm{ppm} \mathrm{Cd}$ alone or with $0.1,0.2$ and $0.3 \mathrm{~g}$ EDTA/L for 3, 10 and 45 days. Cd exposure reduced significantly $(\mathrm{P}<0.05)$ erythrocyte count $(\mathrm{RBCs})$, haemoglobin content $(\mathrm{Hb})$, haematocrit value (Hct), mean cell volume (MCV) mean cell haemoglobin $(\mathrm{MCH})$ and mean cell haemoglobin concentration (MCHC). These parameters were improved when EDTA was applied with $\mathrm{Cd}$. The values of $\mathrm{RBCs}, \mathrm{Hb}, \mathrm{Hct}, \mathrm{MCV}, \mathrm{MCH}$ and $\mathrm{MCHC}$ were increased significantly to be as in the control fish group. There was significant decreases in plasma total protein (TP) in fish exposed to $\mathrm{Cd}$ alone. The levels of plasma glucose, total lipids (LP), aspartate aminotranseferase (AST), alanine aminotransferase (ALT) were increased significantly in fish exposed to $\mathrm{Cd}$ alone. Addition of EDTA to $\mathrm{Cd}$ contaminated medium enhanced biochemical parameters in fish and the enzyme activities returned to be as the control fish group.

Addition of EDTA to Cd contaminated medium considerably reduced metal absorption and its accumulation in fish tissues, and reduced metals in water. Fish exposed to $\mathrm{Cd}$ alone accumulates 2.93, 4.33 and $7.2 \mathrm{mg} \mathrm{Cd} / \mathrm{g}$ dry weight in body fish for 3, 10 and 45 days, respectively. Cd was reduced significantly to $0.13,0.17$ and $0.22 \mathrm{mg}$ $\mathrm{Cd} / \mathrm{g}$ dry weight in fishes exposed to $0.1,0.2$ and $0.3 \mathrm{~g}$ EDTA/L for 3,10 and 45 days, respectively these values were similar to those of control group.
\end{abstract}

Key words:, Clarias gariepinus, cadmium, EDTA, haematology, Biochemistery, glucose, TP, LP, AST and ALT.

\section{INTRODUCTION}

The problems of protecting and improving the environment on a planetary scale is one of the most acute and complex contemporary problems. Interrelations of the environment with the economy fields and all sides of social life leads to a mutual conditioning (Varga \& Sabo 
2009; Petrescu et al., 2010). The impetuous economic and social development of human communities has induced an accelerated environmental change deeply disturbing the natural balance of the compensatory processes in the biosphere (Balan et al., 2010).

Among different types of pollution, the chemical one is more dangerous and obvious, affecting all the components of the biosphere. Chemical compounds have acute or chronic biological effects that depend on many factors (concentration, route of entry, health status, genetic factors etc, (Trif et al., 2010 and Dumitrescu et al., 2010). Hazard degree of these chemical compounds is represented by their toxicity, pollution sources, retention time in the environment, synergic effects, as well as the possibilities of contamination and spread of contaminants (Chiroma et a., 2007 and Fleș eriu, 2010).Increased environmental pollution reflect its impact on the aquatic ecosystems activity. Radioactive, chemical or biological impurities, threaten the balance of these ecosystems. The presence of chemical contaminants in water can have very serious environmental consequences through restructuring of the biocoenosis, altering their integrity and consequently of aquatic ecosystems.

Heavy metals are considered harmful pollutants for the aquatic creatures by themselves or through their toxic salts, which exhibit high stability (Podar, 2010). Contamination of the surface water is made through discharge of wastewater from factories that use such substances in their production processes. The biological activity of these waters can be seriously compromised due to the destruction of a large number of microorganisms and to the inhibition of the methane fermentation process from sludge by the pollutants of this group.

Cadmium is an extremely toxic heavy metal which is widely used in mining, metallurgical operation, electroplating industries, manufacturing vinyl plastics, electrical contacts, metallic and plastic pipes. Effluents from such plants are sources of cadmium into aquatic environments. Most aquatic organisms have the capability of concentrating metals by feeding and metabolic processes, which can lead to accumulation of high concentrations of metals in their tissues. Metals interact with enzymes and may inhibit their biochemical and physiological activities (Passow et al.,1961).

Cadmium and its compounds, compared with other heavy metals, are relatively soluble in water. $\mathrm{Cd}$ is can be mobilized, and: has a great bioavailability and tends to accumulate in living tissues (Nicula $e t$ al., 2010).

Furthermore, cadmium interacts with other essential elements in tissues of several species, showing an antagonistic effect against them. As such, it requires to find scientific detoxification methods to improve the health of economic interest species in any environmental conditions accidental or caused heavy metals discharges can induce severe biochemical changes in normal metabolism of fish. 
The reduction of toxic elements like cadmium in aquatic environments is needed by any acceptable method. The most widely used technique for the removal of toxic elements involves the process of neutralization and metal hydroxide precipitation (Hiemesh and Mahadevaswamy, 1994). Costly chemicals can effectively remove certain toxic elements from industrial wastes or polluted media. However, there are some cheap chemicals which are also free from undesirable side effects. In recent years, the remobilization of metals by synthetic anthropogenic chealting agents has received much attention. The literature reported number of chelators that have been used for chelate-induced hyperaccumulation (Huang et al.,1997). Synthetic compound like ethylenediamine tetraacetic acid (EDTA) is known to be effective chelating agents of heavy metals (Licop, 1988 and James et al., 1998). EDTA is the most commonly used as chelator due to its strong chelating ability for different heavy metals (Norvell, 1991). EDTA has two advantages its relative low biodegradability in groundwater systems (Nowack, 1996) and its strong complexing capacity with heavy metals (Kedziorek and Bourg, 2000).

Metal bioaccumulation can occur via complexation, coordination, chelation, ion exchange and other processes of greater or lesser specificity. Bioaccumulation processes are sometimes due to active (metabolism dependent) metal accumulation by living cells. In other cases, bioaccumulation is a strictly aggressive process in which metal ions are sequestered by metal binding site in the interior of the cell. The removal of toxic elements from contaminated water, has potential advantages over the conventional treatment process; ion exchange, precipitation, etc. ( Kuyack and Volesky, 1990).

In spit of the amount of data published on the effect of waterborne exposure of cadmium and EDTA singly, information on the effects of Cd / EDTA mixture on aquatic organisms are limited. EDTA appears to be promising tool to control cadmium pollution in aquaculture. In the present study, short and longterm bioassays were designed to evaluate the influence of EDTA on the retention of cadmium in water. Also the study was carried out to investigate the effect of EDTA on reduction of toxicity of cadmium and to enhance the blood parameter and enzymes of cat fish (Clarias gariepinus).

\section{MATERIALS AND METHODS Fish Culture Management:}

Healthy ca fish ( Clarias gariepinus) weighing 160- $180 \mathrm{~g} /$ fish were collected from the ponds of Central Laboratory for Aquaculture Research at Abbassa, Abo-Hammad, Sharkia, Egypt. Fish were acclimated in an indoor tank for 2 weeks to laboratory conditions.

Acclimated fish were exposed to different concentration of cadmium and mortality rates were observed for 96- h. A static renewable bioassay method (Spraggue, 1973) and the median lethal probity analysis (Litchfield and Wileoxon 1949) was adopted for the determination of $96-\mathrm{h}$ $\mathrm{LC}_{50}$. A control group was 
maintained in metal -free tap water. The $96 \mathrm{hr} \mathrm{LC}_{50}$ of cadmium for Clarias garbinus was 48 ppm. A stock solution of cadmium was prepared by dissolving $12.16 \mathrm{~g}$ of annular grad cadmium sulphate $\left(\mathrm{CdSO}_{4}-8 / 3 \mathrm{H}_{2} \mathrm{O}\right)$ in one liter of distilled water and the diluted with water to obtain the desired concentration (12 ppm) for this experiment.

Table (1): Experimental groups and their notation.

\begin{tabular}{clc}
\hline S.No. & Groups & Nation \\
\hline 1 & Control (metal free water) & $\mathrm{C}$ \\
2 & Cadmium $(12 \mathrm{ppm})$ alone & $\mathrm{Cd}$ \\
3 & Cadmium $(12 \mathrm{ppm})+0.1 \mathrm{~g}$ & CdEDTA1 \\
& EDTA/l & \\
4 & Cadmium (12 ppm) +0.2 & CdEDTA2 \\
& EDTA/l & \\
5 & Cadmium (12 ppm) $+0.3 \mathrm{~g}$ & CdEDTA3 \\
\hline
\end{tabular}

Fish were distributed randomly in 120-liter glass aquaria, at a rate of 10 fish / aquarium that containing aerated tap water. These aquaria were divided into five groups with three replicates each per group. The first group was free of $\mathrm{Cd}$ and EDTA and maintained as a control. The second group was exposed to $12 \mathrm{ppm}$ of $\mathrm{Cd}$ $\mathrm{SO}_{4}$ only. (Equivalent to $1 / 496 \mathrm{hr}$ $\mathrm{LC}_{50}$ ). The third, fourth and fifth groups were exposed to $12 \mathrm{mg} \mathrm{Cd} / 1$ and $0.1,0.2$ and $0.3 \mathrm{~g}$ EDTA/l, respectively. Each aquarium was supplied with compressed air via airstones from air pumps. Well-aerated water supply was provided from a storage fiberglass tank. The temperature was adjusted at $27^{\circ} \mathrm{C}$ by means of thermostats.

Cadmium sulphate and EDTA was obtained from El- Nasr chemical company (Egypt) and prepared in aquatic solution to provide the required concentrations of cadmium and EDTA.
Fish were fed frequently a diet containing $30 \%$ crude protein $(\mathrm{CP})$ at a rate of $3 \%$ of live body weight twice daily. The exposure periods were 3 , 10 and 45 days. Siphoning three quarters aquariums was done every day for waste removal and replacing it by an equal volume of water containing the same concentration of $\mathrm{Cd}$ and EDTA. Dead fish were removed and recorded daily.

\section{Physiological Analyses:}

After 3, 10 and 45 days of the experiment,. samples of blood were taken from three catfish from each aquarium.

Fish were not fed for $24 \mathrm{~h}$ before sampling and were anaesthetized with buffered MS222 (50 mg /L) and blood samples were taken from caudal vein of fish by sterile syringe using EDTA solution as anticoagulant. These blood samples were used for determining erythrocyte count (Dacie and Lewis 1984) and hemoglobin content (Van Kampen,and Ziijlstra, 1961). Heamatocrit value (Hct) were calculated according to the formulae mentioned by Britton (1963). The blood relative indices $(\mathrm{MCV}<\mathrm{MCH}$ \& $\mathrm{MCHC}$ ) were calculated by equation recommended for each

Plasma was obtained by centrifugation of blood at $3000 \mathrm{rpm}$ for $15 \mathrm{~min}$ and nonhaemolyzed plasma was stored in deep freezer for further biochemical analyses. After decapitation of fish, collected all fish in each group for determined $\mathrm{Cd}$ residue in whole body fish. Plasma glucose was determined, using glucose kits supplied by Boehring Mannheium kit, according to Trinder (1969). Total protein content was 
determined colorimetrically according to Henry (1964). Total lipids contents were determined colorimetrically according to Joseph et al. (1972). Activities of aspartate amninotransferase (AST) and alanine aminotransferase (ALT) were determined colorimetrically according to Reitman and Frankel (1957).

\section{Cd residue :}

Cadmium was measured in water and in the whole body fish according to the method of (Eaton and Stinson, 1983).

\section{Statistical Analysis:}

The obtained data were subjected to analysis of variance according to Snedecor and Cochran (1982). Differences between means were done at the $5 \%$ probability level, using Duncan's new multiple range test (Duncan, 1955).

\section{RESULTS}

The present study showed that the addition of EDTA to $\mathrm{Cd}$ contaminated media, reduced significantly the Cd level in water and helped to eliminate itfrom the fish body, which in turn improved haematological and biochemical parameters as compared to fish exposed to cadmium alone.

\section{Haematological parameters:}

The results of erythrocyte count (RBCs), haemoglobin content $(\mathrm{Hb})$ and haemetocrit value ( $\mathrm{Hct}$ ) obtained from the fish exposed to sublethal dose of Cd (12 mg/l) alone or with different doses of EDTA are given in table (2). The results indicated that the values of RBCs, $\mathrm{Hb}$ and $\mathrm{Hct}$ were reduced in fish exposed to $\mathrm{Cd}$ at three periods and they were less than that of the control
$(\mathrm{P}<0.05)$. The RBCs count decreased significantly (1.41, 1.47 and 1.64 million/ $\mathrm{mm}^{3}$ ) in fish exposed to $\mathrm{Cd}$ at 3,10 and 45 days respectively, when compared with the control group $(2.17, \quad 2.19$ and 2.47 million $/ \mathrm{mm}^{3}$ ). On the other hand, the values of RBCs, $\mathrm{Hb}$ and $\mathrm{Hct}$ parameters returned to their normal values in fish exposed to $\mathrm{Cd}$ with 0.2 and $0.3 \mathrm{~g}$ of EDTA/1 for all exposed periods. These values increased nonsignificantly in fish exposed to $\mathrm{Cd}$ with $0.3 \mathrm{~g}$ EDTA/ 1 at 45 days.

The blood indices calculated from the mean values of blood parameters for the aforementioned treatments are given in table (3). Data showed that the MCV increased significantly in fish exposed to $\mathrm{Cd}$ alone, while the $\mathrm{MCH}$ and MCHC decreased significantly in catfish exposed to $\mathrm{Cd}$ only when compared with the control. These parameters increased with the increasing of exposure time of fish to $\mathrm{Cd}$. Addition of EDTA to Cdpolluted media maintained the MCV, $\mathrm{MCH}$ and $\mathrm{MCHC}$ at levels close to those of the control.

\section{Biochemical parameters:}

As demonstrated in table (4) the plasma glucose concentration showed higher significant values $(\mathrm{P}<0.01)$ $(166.3 \pm 5.7,154.8 \pm 3.96$ and 141.06 $\pm 3.85 \mathrm{mg} \%)$ in fish exposed to $\mathrm{Cd}$ alone for 3,10 and 45 days, respectively when compared with the control fish group values. The glucose concentration in fish subjected for $\mathrm{Cd}$ with 0.2 and $0.3 \mathrm{~g} \mathrm{EDTA} / \mathrm{L}$ did not significantly be affected. After all periods of exposure, the plasma glucose concentration were non significantly increased in all treatments. 
As seen in table (4) there was significant variation in the plasma total protein of nearly all fish under investigation after 3,10 and 45 days of exposure. The plasma total protein decreased significantly to be $3.45 \pm$ $0.164,3.54 \pm 0.148$ and $2.29 \pm 0.151$ $\mathrm{g} / 100 \mathrm{ml}$ in fish exposed to $\mathrm{Cd}$ alone in all exposed periods. Also, plasma protein values decreased significantly $(3.61 \pm 0.235$ and $3.2 \pm 0.226$ $\mathrm{g} / 100 \mathrm{ml}$ ) in fish exposed to mixture of Cd with $0.1 \mathrm{~g}$ EDTA/Lfor 10 and 45 respectively compared with control group. Plasma protein value decreased non significantly after exposing fish to mixture of $\mathrm{Cd}$ with 0.2 and $0.3 \mathrm{~g}$ EDTA/L.

It can be seen from data given in table (4) values of plasma total lipids were increased significantly in fish exposed to $\mathrm{Cd}$ alone in all periods and Cd with $0.1 \mathrm{~g} \mathrm{EDTA} / \mathrm{L}$ for 3 and 10days when compared to the control group, while these were similar to the control group in fish exposed to mixture of $\mathrm{Cd}$ with $0.2 \mathrm{~g}$ and $0.3 \mathrm{~g}$ EDTA/L for all exposed periods.

Table (5) showed that AST activity increased significantly in plasma of fish exposed to $\mathrm{Cd}$ alone. The addition of EDTA decreased significantly the AST activity to be less than that in fish treated with $\mathrm{Cd}$ alone $(\mathrm{P}<0.05)$. The AST activity in fish exposed to $\mathrm{Cd}$ with $0.3 \mathrm{~g}$ EDTA/L became similar to that of control group at 3,10 and 45 days. The plasma ALT activity also increased significantly in fish exposed to $\mathrm{Cd}$ alone at 3,10 and 45 days $(63.82 \pm 1.23,60.53 \pm 1.93$ and $87.59 \pm$ 2.23 IU/L, respectively). The addition of EDTA enhanced ALT activity to be as that in the control group especially the groups exposed to $\mathrm{Cd}$ with 0.2 and $0.3 \mathrm{~g} \mathrm{EDTA/L}$ at all periods.

\section{Cd bioaccumulation :}

Addition of EDTA to the $\mathrm{Cd}$ polluted media reduced significantly $(\mathrm{P}<0.05)$ the $\mathrm{Cd}$ level in water as compared to that of $\mathrm{Cd}$ alone (Table $6)$. The $\mathrm{Cd}$ concentration in water with $\mathrm{Cd}$ alone $(11.98 \mathrm{mg} / \mathrm{L})$ decline significantly $(\mathrm{P}<0.05)$ to $7.15,4.79$, and $2.73 \mathrm{mg} / \mathrm{l}$ after additives ( 0.1 , 0.2 and $0.3 \mathrm{~g}$ EDTA/L) respectively. The data showed a wide variation among the different groups of catfish subjected to $\mathrm{Cd}$ alone or $\mathrm{Cd}$ with different doses of EDTA. The highest amount of $\mathrm{Cd}$ residue was found in whole fish group exposed to cadmium alone and the lowest amount in fish group exposed to mixture of $0.3 \mathrm{mg}$ EDTA with $\mathrm{Cd}$ in all periods ( Table 6).

\section{Discussion}

The importance of haematology in diagnosis of fish diseases and assessment of the effect of cadmium polluted has been widely accepted The present study reveals that the fish exposed to $\mathrm{Cd}$ alone showed significant reduction in their RBCs, $\mathrm{Hb}$ and Hct than those exposed to $\mathrm{Cd}$ with different levels of EDTA. The reduction of these parameters in catfish, Clarias gariepinus at sublethal levels of cadmium might be due to the destruction of mature RBCs and the inhibition of erythrocyte production due to reduction of haemsynthesis that affected by pollutants (Wintrobe, 1978) and because the cadmium circulates in the blood primarily bound to the red cells. It is evidently bound partly to haemoglobin and 
partly to metalllothionein (Webb \& Verscheyle, 1976). Interaction of cadmium with iron in the plasma will impaired haem production necessary for erythrocyte haemoglobin synthesis and causes anemia as reported by (Moshtaghie et al., 1994 and Karuppasamy et al., 2005). Also, the decrease in RBCs count may be attributed to haematopathology or acute haemolytic crisis that results in sever anemia in most vertebrates including fish species exposed to different environmental pollutants (khangarot and Tripathi, 1991) or may be due to reduction of growth and other food utilization parameters which results in sever aneamia (James and Sampath, 1999). Also Gill and Epple (1993) found a significant reduction in the RBCs, $\mathrm{Hb}$ and Hct in American eel (Anguilla rostrata) after exposure to 150 ug $\mathrm{Cd} / \mathrm{L}$. Karuppasamy et al (2005) found a significant decreased in total erythrocyte count, haemoglobin content, haematocrit value and mean corpuscular haemoglobin concentration in air breathing fish, Channa punctatus after exposure to sublethal dose of Cd (29 mg Cd/L).

The addition of EDTA improves the haematological parameters (RBCs, $\mathrm{Hb}$ and $\mathrm{Hct}$ ) which can be attributed to the capability of EDTA to chelate $\mathrm{Cd}$ from the media and subsequently, the $\mathrm{Cd}$ toxicity was reduced. These results are in agreement with those of James et al. (1998) who observed that Oreochromis mossambicus exposed to copper along with EDTA showed a significant improvement in blood parameters over those copper alone.

The calculated blood indices
MCV, MCH and MCHC have a particular importance in anemia diagnosis in most animals (Coles, 1986). The perturbations in these blood indices (increase MCV, decrease of $\mathrm{MCH}$ and $\mathrm{MCHC}$ ) may be attributed to a defense against $\mathrm{Cd}$ toxicity through the stimulation of erythropiosis or may be related to the decrease in RBCs, $\mathrm{Hb}$ and Hct due to the exaggerated disturbances that occurred in both metabolic and hemopoietic activities of fish exposed to sublethal concentration of pollutants (Moussa, 1999).

The present results indicated that EDTA was effective in reducing $\mathrm{Cd}$ from water and from tissue of fish. Santschi (1988) reported that any agent that can remove $\mathrm{Cd}$ from water helps to reduce the bioaccumulation of this metal in fish. Particulate organic matter can also scavenge metal from water and help to reduce metal from fish.

Blood glucose is a sensitive reliable indicator of environmental stress in fish. From the present results , it was clear that $\mathrm{Cd}$ elevated blood glucose level in catfish. Sastry and Subhadra, (1985) reported that $\mathrm{Cd}$ induced hyperglycemia with decreased in liver glycogen in catfish, Heteropneustes fossilis. Soengas et al (1996) suggested that hyperglycemia occurred in Atlantic salmon (Salmo salar) after toxicity with cadmium, may be due to change in liver carbohydrate metabolism (activation of liver glycogenolysis and glycolysis) as well as increased levels of plasma glucose and lactate. However, the reduction of glucose concentration in plasma of catfish along with EDTA in the present work 
is due to the removal of Cd by EDTA.

One of the important functions of serum protein is the maintenance of osmotic balance between the circulating blood and the tissue fluids (Haper et al., 1977). The influence of toxicants on the total protein concentration of fish has been also taken into consideration in evaluating the response to stressors and consequently the increasing demand for energy. The total protein level is a frequently parameter of metal poisoning in fish. However, data available did not allow to assessment of the direction of these changes, since the same metal may cause both increase and decrease of total protein. From the present results the plasma total protein were decreased significantly in fish exposed to $\mathrm{Cd}$ only or with low levels of EDTA at 10 and 45 days. This may be attributed to the cellular damage that occurred in the tissues of $\mathrm{Cd}$ toxicated fish, $\mathrm{Cd}$ toxicity may cause protein breakdown. The addition of chelating agent EDTA to Cd polluted media reduced significantly the retention of $\mathrm{Cd}$ in fish body and this indirectly improved the growth and biochemical changes. James and Sampath (1999) found similar results with catfish Heteropneustes fossilis.

Lipids because of their rapid metabolic transformation are considered transient body material, but they represent the major source of stored chemical energy and their absence reflects the physiological capacity of fish (Schreck and Moyle, 1990). The present results indicated that total lipids in plasma increased significantly in fish exposed to $\mathrm{Cd}$ alone. On the other hand, addition of
EDTA lowered total lipids in fish exposed to cadmium toxicity to be similar to that of the control fish. Shalaby (2001) reported that the absorption of excess heavy metals disturbed the metabolism of lipid..

The activity of AST and ALT enzymes in blood can be used as a stress indicator. The significant changes in activities of these enzymes in blood plasma indicate tissue impairment caused by stress (James et al., 1991 and Svoboda, 2001). In the present study, there were significant changes in AST and ALT activities in plasma of fish exposed to cadmium compared to the control group. The increase in concentration of AST and ALT in blood plasma indicates impairment of parenchymatous organs (liver). Yamawaki et al. (1986) stated that the increase of plasma AST and ALT may be attributed to the hepatocellular damage or cellular degradation by these heavy metal, perhaps in liver, heart or muscle. Also, Shalaby (1997) found that sublethal concentration of $\mathrm{Cd}$ caused significant increases in AST and ALT of common carp after 7 and 15 days.

The present study showed that the addition of EDTA to the $\mathrm{Cd}$ media reduced significantly the $\mathrm{Cd}$ level in water and metal uptake as compared to fish exposed to $\mathrm{Cd}$ alone. The $\mathrm{Cd}$ accumulation in whole body fish exposed to $\mathrm{Cd}$ alone was higher than that of EDTA. These results suggest that EDTA could chelate $\mathrm{Cd}$ ions producing a stable complex, thus reducing the chance for metal uptake by tissues. The formation of $\mathrm{Cd}$ EDTA complex in water and 
elimination of more amount of $\mathrm{Cd}$ in feces evidently reduced the metal burden in tissues and thereby improved the haematological and biochemical parameters of fish exposed to $\mathrm{Cd}$. ( Planas- Bohne and Lehman, 1983) found low level of cadmium in tissues due to increased excretion of metals through feces and urine when rats were administered $\mathrm{Cd}$ intravenously along with EDTA. From the present study, it is recommended that an optimum dosage of $0.3 \mathrm{~g}$ EDTA/l can effectively chelate $\mathrm{Cd}$ from contaminated water and improve physiological aspects and activities of fish. The addition of EDTA to $\mathrm{Cd}$ contaminated media, reduced significantly the $\mathrm{Cd}$ level in the water and helped to eliminate metal from the fish body and in turn improved the biochemical parameters as compared to fish exposed to $\mathrm{Cd}$ alone.

\section{REFERENCE}

Balan, L..; Tipa, S.; Doval, E and Micu, D. (2010): Environmental pollution and human health. Metalurg. Intern., 15 (9) 56-60.

Britton, C.J. (1963): Disorders of the Blood $9^{\text {th }}$ ed. I. A. Churchill, Ld. London pp:320.

Chiroma, T. M.; Abdulkarim, B. I. and Kefas, H. M.(2007): The impact of pesticide application on heavy metal $(\mathrm{Cd}, \mathrm{Pb}$ and $\mathrm{Cu})$ levels in spinach. Leonardo J. of Pract. and Technol., 6 (11) 123130.

Coles, E. H. (1986): Veterinary Clinical Pathologye. edt .W. B. Saunders, Philadelphia., 10- 42.
Dacie, J. V. and Lewis, S. M. (1984): Practical Haematology. Churchill Living Stone. London . pp: 187.

Dumitrescu E.: Trif, A.: Brezovan, D.: Cristina, R. T. and Petrovici S.(2010): The consequences of lead acetate intake on exposure and integrity biomarkers of reproductive system in female rats at sexual maturity (two generation study). HVM Bioflux., 2 (1) pp:19-24

Duncan, D. B. (1955): Multiple range and multiple (F) test. Biometri., 11 pp: 1- 42.

Eaton, D. L and Stinson, M. D. (1983): Concentration of lead , cadmium, mercury and copper in the cray fish (Pacifasticus leniusculus) obtained from a lake receiving urban runoff. Arch. Environ. Contam. Toxicol., 12, 693- 700 .

Fles eriu, A.(2010): Endocrine disrupting pesticides and their impact on wildlife and human health. HVM Bioflux, 2 (1) 1-4.

Gill, T.S and Epple, A. (1993): Stress-related changes in the hematological profile of the American eel (Anguilla rostrata). Ecotoxicol. Environ. Saf., 25 (2) 227-35.

Haper, H. A.; Roodwell, V. W. and Mayes, P. A. (1977): Review of Physiological Chemistry. Lang. Medical Publications, Los Angeles, CA. pp: 254.

Henry, R. J. (1964): Colorimetric determination of total protein. In: Clinical Chemistry. Harper and 
Row Publ., New York, pp 181.

Hiemesh, S. and Mahadevaswamy, M. (1994): Sorption potential of biosorban: for the removal of copper. Indian. J. Environ. Hlth., 36, 165- 169.

Huang, J. W.; Chen, J.; Berti, W. R. and Cunningham S. D (1997): Phytoremediation of $\mathrm{Pb}$ contaminated soils: Role of synthetic chelates in lead phytoextraction. Environ. Sci. Technol., 31, 800- 805.

James, R. and Sampath, K (1999): Effect of the ion- exchanging agent, Zeolite, on reduction of cadmium toxicity: an experimental study on growth and elemental uptake in Heteropneustes fossilis (Bloch). J. Aqua. Trop., 14 (1) 65- 74.

James, R.; Sampath, K and Selvamani, P (1998): Effect of EDTA on reduction of copper toxicity in Oreochromis mossambicus. Bull. Environ. Contam.Toxicol., 60, 478-493.

James, R.; Sivakumar, V.; Sampath, K. and Rajendran, P. (1991): Individual and combined effects of zinc ; cadmium and copper on growth of Oreochromis mossambicus. Indian. J. Fish., 38, 198- 200

Joseph, A.; Knight, M.; Anderson, S.; James, M. and Rawie, $H$. (1972): Chemical basis of the sulfophospho-vanillin reaction for estimating total serum lipid. Clin. Chem., 18 (3) 198-201.

Karuppasamy, R.; Subathra and Puvaneswari, S. (2005):
Haematological responses to exposure to sublethal concentration of cadmium in air breathing fish, Channa punctatus (Bloch). J. Environ. Biol., 26 (1) 123-8.

Kedziorek, M. A. M and Bourg, A. S. M (2000): Solubilization of lead and cadmium during the percolation of EDTA through a soil polluted by smelting activites. Contam. Hydrol., 40, 381-392.

Khangarot, B. S and Tripathi, D. M (1991): Changes in humoral and cell- mediated immune responses and in skin and respiratory surfaces of catfish Saccobranchus fossillis, following copper exposure. Ecot. Envir. Safety., 22 (3) 291- 308.

Kuyack, N and Volesky, B ( 1990): Biosorption of heavy metal, CRC Press, Boca Raton 174- 198.

Litchfield, J. T and Wileoxon, F. ( 1949): A simplified method for evaluatin dose- effect experiments. J. Pharmacol. Exp. Ther., 96, 59-113.

Licop, M. S. (1988): Sodium- EDTA effect on survival and metamorphosis of Penaeus monodon larvae. Aquac., 74, 239247

Moshtaghie A. A., Taghikhani, M. and Sandughchin M. (1994): Cadmium interaction with iron metabolism, in vitro and in vivo studies. J.of Islamic Acad. Sci., 7 (3) $145-150$.

Moussa, M. A. (1999): Biological and physiological studies on the effect of the gramoxon and stomp 
herbicides on Nile tilapia (Oreochromis niloticus). Ph.D. Thesis, Fac. Sci. Zool. Dep. Cairo. Univ., 200p.

Nicula, M.; Banatean-Dunea, I.;: Gergen, I.; Harmanescu, M.; Simiz E., Patruica, S.; Polen, T.:, Marcu, A.: Lunca, M. and Szucs S.(2010): Effect of natural zeolite on reducing tissue bioaccumulation and cadmium antagonism related to some mineral micro- and macronutrients in Prussian carp (Carassius gibelio). AACL Bioflux, 3(3) 171179.

Norvell, W.A (1991): Reactions of metal chelates in soil and nutrient solutions In: Mortvedt, J.J., Cox, F.R.,Shuman, L. M and Welch, R. M., Editors, 1991. Micronutrients in Agriculture, $2^{\text {nd }}$ Edition, Soil. Science of America, Madison, Wisconnsin, 187- 227.

Nowack, B (1996): Behavior of EDTA in groundwater- a study of the surface reactions of EDTAmetal complexes. Doctoral thesis, E. T. H. Nr: 11392. Zurich. Switzerlasnd, pp.175.

Passow, H.; Rothstein, $A$ and Clarkson, T. W. (1961): The general pharmacology heavy metals . Pharmacol. Rev., 33, 185224.

Petrescu, D. C.; Bran, F and Petrescu-Mag, R. M.( 2010): The water footprint and its impact on sustainable water consumption. Metalurgia International., 15 (Sp.iss.1) 81-86.

Planas- Bohne, $\mathbf{F}$ and Lehman, $M$ (1983): Influence of chelating agent on the distribution and excretion of cadmium in rats. Toxicol. Appl. Pharmacol., 67, 408- 416.

Podar, D. (2010): Plant transporters involved in heavy metal homeostasis. ELBA Bioflux, 2(2):82-87.

Reitman, S. and Frankel, S. (1957): Colorimetric determination of glutamic oxaloacetic and glutamic pyruvic transaminases. Amer. J. Clin. Pathol., 28, 53-56.

Santschi, P. H (1988): Factors controlling the biogeochemical cycle of trace elements in fresh and coastal waters as revealed by artificial radioisotopes. Limnol. and Oceanogr., 33, 848- 886.

Sastry, K. V and Subhadra, K (1985): In vivo effects of cadmium on some enzyme activities in tissues of the freshwater catfish, Heteropneustes fossilis. Environ. Res., 36 (1) 3245.

Schreck, C. B. and Moyle, P. B. 1990): Methods of Fish Biology. Am. Fish. Soc. Bathesda. Maryland.

Shalaby , A. M. (1997): Biochemical and physiological studies on metal contamination in the common carp (Cyprinus carpio L). Ph.D. Thesis, Fac. of Scie. (Benha branch). Zagazig Univ, 268p.

Shalaby, A. M. (2001): Protective effect of ascorbic acid against mercury intoxication in Nile tilapia (Oreochromius niloticus). J. Egypt. Acad. Soc. Environ. Develop., (D- Environmental 
studies)., 2 (3) 79-97.

Snedecor, G. W. and Cochran, W. G. (1982): Statistical Methods. 6th edition. Iowa State Univ. Press., Amer., IA, USA, pp 593.

Soengas, J. L.; Agra-Lago, M. J.; Carballo, B.; Andres, M. D and Veira, J. A. R (1996): Effect of an acute exposure to sublethal concentration of cadmium on liver carbohydrate metabolism of Atlantic salmon (Salmo salar). Bull. Environ . Contam. Toxicol., 57, 625- 631.

Spraggue, J. B( 1973): The ABCs of pollutant bioassay using fish In Biological Methods for Assessment of Water Quality. ASTM 528. Amer. Testing. Material., 6-30.

Svoboda, M (2001): Stress in fish review. Bul. VURH Vodnany., 37, 69- 191.

Trif A.; Dumitrescu, E.; Brezovan, D. and Petrovici, S.(2010): The consequences of aluminium sulphate intake on exposure and integrity biomarkers in female rats at sexual maturity (two generation study). HVM Bioflux., 2(1), 11-..
Trinder, P. (1969): Determination of glucose concentration in the blood. Ann. Clin. Biochem., 6, 24 p.

Van Kampen, E. J. and Zijlstra, N. C. (1961): Determination of haemoglobin. Clin. Chem. Acta, 5, 719-720.

Varga, I. M. and Sabo, H. M. (2009): The sustainable development and the environmental protection. Ecoterra, 23, 31-33.

Webb M. and Verscheyle R. D. (1976): An investigation of the role of metallothioneins in protection against the acute toxicity of the cadmium ion. Biochem. Pharmacol., 25, 673680.

Wintrobe, M. M (1978): In: Clinical hematology. Henry Kimpton, London., pp: 448.

Yamawaki, K.; Hashimoto, W.; Fujii, K.; Koyama, J.; Ikeda, Y. and Ozaki, H. (1986): Hematological changes in carp exposed to low cadmium concentration . Bull. Japanese. Soc. Sci. Fish., 59 (3) 4, 59- 466. 
Table (2): Changes in erythrocyte (count $\left.\times 10^{6} / \mathrm{mm}^{3}\right)$, hemoglobin content $(\mathrm{g} / 100 \mathrm{ml})$ and haematocrit value $(\%)$ in the blood of catfish $(C l a r i a s$ garopeinus) exposed to $\mathrm{Cd}(12 \mathrm{mg} / \mathrm{l})$ with and without EDTA.

\begin{tabular}{|c|c|c|c|c|c|c|c|c|c|}
\hline & \multicolumn{3}{|c|}{ Erythrocyte count (RBCs) } & \multicolumn{3}{|c|}{ Hemoglobin (HB) } & \multicolumn{3}{|c|}{ Haematocrit value (Hct) } \\
\hline & 3 days & 10 days & 45 days & 3 days & 10 days & 45 days & 3 days & 10 days & 45 days \\
\hline Control & $2.17 \pm 0.22$ & $2.19 \pm 0.14$ & $2.47 \pm 0.17$ & $8.27 \pm 0.09$ & $8.41 \pm 0.73$ & $9.88 \pm 0.96$ & $27.4 \pm 2.88$ & $34.25 * * * \pm 2.21$ & $31.5 \pm 2.38$ \\
\hline Cd & $1.41 * \pm 0.19$ & $1.47 * * \pm .11$ & $1.64 * * * \pm .14$ & $5.04 * \pm 0.36$ & $4.63 * * \pm 0.76$ & $4.75 * * \pm 0.96$ & $20.6 * \pm 0.39$ & $12.75^{* *} \pm 2.62$ & $17.5^{* * *} \pm 2.08$ \\
\hline Cd+0.1g EDTA/l & $1.54 * \pm 0.07$ & $1.08 * \pm 0.34$ & $1.79 * * \pm 0.02$ & $5.72 \pm 0.92$ & $6.43 \pm 0.371$ & $7.19 \pm 0.83$ & $23.0 \pm 2.4$ & $21.5^{* *} \pm 2.38$ & $18.33 * * \pm 1.52$ \\
\hline $\mathrm{Cd}+0.2 \mathrm{~g}$ EDTA/l & $1.92 \pm 0.05$ & $2.02 \pm 0.10$ & $2.03 \pm 0.10$ & $7.97 \pm 0.78$ & $8.07 \pm 1.17$ & $9.02 \pm 0.30$ & $25.66 \pm 2.87$ & $32.5 \pm 2.62$ & $27.25 \pm 2.21$ \\
\hline Cd+0.3g EDTA/l & $2.07 \pm 0.24$ & $2.16 \pm 0.12$ & $2.52 \pm 0.07$ & $8.15 \pm 0.91$ & $8.68 \pm 0.65$ & $9.7 \pm 0.2$ & $27.66 \pm 3.03$ & $33.25 \pm 4.25$ & $34.66 \pm 1.52$ \\
\hline
\end{tabular}

Data are represented as means \pm S.E $*$ Significant at $\mathrm{P}<0.05 * *$ Significant at $\mathrm{P}<0.01$

$$
* * * \text { Significant at } \mathrm{P}<0.001
$$

Table (3): Changes in mean corpuscular volume(MCV), mean corpuscular haemoglobin ( MCH) and mean corpuscular haemoglobin concentration (MCHC) in the blood of catfish (Clarias garopeinus) exposed to Cd (12mg/l) with and without EDTA.

\begin{tabular}{|c|c|c|c|c|c|c|c|c|c|}
\hline & \multicolumn{3}{|c|}{ MCV (cubic micrometer um3) } & \multicolumn{3}{|c|}{ MCH ( Picogram cell) } & \multicolumn{3}{|c|}{ МСНC (\%) } \\
\hline & 3 days & 10 days & 45 days & 3 days & 10 days & 45 days & 3 days & 10 days & 45 days \\
\hline Control & $106.26 \pm 9.92$ & $90.93 \pm 7.90$ & $122.27 \pm 5.18$ & $44.59 \pm 4.10$ & $47.62 \pm 4.90$ & $38.76 \pm 2.30$ & $41.97 \pm 0.78$ & $33.27 \pm 0.38$ & $36.71 \pm 2.04$ \\
\hline Cd & $183.98 * * * \pm 8.60$ & $187.53 * * * \pm 3.46$ & $138.42 * \pm 2.90$ & $30.74 * \pm 3.91$ & $31.25 * * \pm 1.32$ & $33.87 \pm 0.21$ & $17.38 * * * \pm 2.12$ & $24.68 * * * \pm 1.02$ & $29.60 * \pm 1.93$ \\
\hline Cd+0.1g EDTA/l & $176.03 * * * \pm 2.10$ & $122.82 * * \pm 3.94$ & $111.70 \pm 4.53$ & $41.72 \pm 6.82$ & $35.17 * \pm 0.90$ & $43.65 \pm 0.97$ & $22.65 * * * \pm 3.35$ & $31.74 \pm 2.05$ & $31.75 \pm 2.19$ \\
\hline Cd+0.2g EDTA/l & $131.20 * * * \pm 6.50$ & $111.07 \pm 5.49$ & $136.95 * \pm 3.85$ & $38.97 \pm 2.53$ & $40.93 \pm 1.75$ & $38.10 \pm 0.48$ & $34.05 * * * \pm 0.65$ & $31.85 \pm 0.79$ & $28.84^{*} \pm 1.03$ \\
\hline Cd+0.3g DTA/l & $126.48 * * * \pm 3.09$ & $144.62 \pm 2.40$ & $121.55 \pm 3.96$ & $48.32 \pm 1.81$ & $49.74 \pm 8.05$ & $41.74 \pm 5.02$ & $44.52 \pm 1.18$ & $35.21 \pm 2.02$ & $37.41 \pm 1.01$ \\
\hline
\end{tabular}

Data are represented as means \pm S.E *Significant at $\mathrm{P}<0.05 * *$ Significant at $\mathrm{P}<0.01 * * *$ Significant at $\mathrm{P}<0.001$ 
Table (4): Changes in the Glucose, Protein and Total lipids in the blood of catfish (Clarias garopeinus) exposed to Cd (12mg/l) with and without EDTA.

\begin{tabular}{|c|c|c|c|c|c|c|c|c|c|}
\hline & \multicolumn{3}{|c|}{ Glucose } & \multicolumn{3}{|c|}{ Protein } & \multicolumn{3}{|c|}{ Total lipids } \\
\hline & 3 days & 10 days & 45 days & 3 days & 10 days & 45 days & 3 days & 10 days & 45 days \\
\hline Control & $108.4 \pm 1.43$ & $60.91 \pm 3.96$ & $92.06 \pm 5.0$ & $4.43 \pm 0.235$ & $4.43 \pm 0.149$ & $4.01 \pm 0.277$ & $14.54 \pm 0.821$ & $15.84 \pm 0.759$ & $15.3 \pm 1.5$ \\
\hline Cd & $166.3^{* * *} \pm 5.7$ & $154.8 * * * \pm 3.96$ & $141.06^{* * *} \pm 3.85$ & $3.54 * * \pm .164$ & $3.54 \pm .148^{* * *}$ & $2.29 * * \pm .151$ & $34.77 \pm 1.12 * * *$ & $36.11 \pm 9.55 * * *$ & $58.5^{* * * * \pm 1.34}$ \\
\hline Cd+0.1g EDTA/l & $122.4 \pm 8.15$ & $79.8 * * * \pm 3.77$ & $138.38 * * * \pm 6.05$ & $3.87 \pm 0.161$ & $3.61 \pm 0.235^{*}$ & $3.20 \pm 0.226^{*}$ & $18.756 \pm .651 * *$ & $29.5 \pm 2.56^{* * *}$ & $15.3 \pm 0.5$ \\
\hline $\mathrm{Cd}+0.2 \mathrm{~g}$ EDTA/l & $115.0 \pm 1.66$ & $67.35 \pm 1.87$ & $98.8 \pm 3.04$ & $3.89 \pm 0.254$ & $4.06 \pm 0.134$ & $3.38 \pm 0.161$ & $13.22 \pm 0.402$ & $19.73 \pm 2.34$ & $13.31 \pm 0.922$ \\
\hline Cd+0.3g EDTA/l & $109.0 \pm 1.86$ & $69.1 \pm 2.19$ & $95 . .2 \pm 0.97$ & $4.21 \pm 0.185$ & $4.14 \pm 0.151$ & $3.59 \pm 0.198$ & $15.81 \pm 0.462$ & $16.56 \pm 0.89$ & $14.39 \pm 0.61$ \\
\hline
\end{tabular}

Data are represented as means \pm S.E *Significant at $\mathrm{P}<0.05 * *$ Significant at $\mathrm{P}<0.01 * * *$ Significant at $\mathrm{P}<0.001$

Table (5): Changes in aspartate aminotransferase activity (AST)_and alanine aminotransferase (ALT) activity (IU/L) in plasma of catfish Clarias gariepinus) exposed to $\mathrm{Cd}(12 \mathrm{mg} / \mathrm{l})$ with or without EDTA.

\begin{tabular}{|c|c|c|c|c|c|c|c|c|c|}
\hline & \multicolumn{3}{|c|}{ Glucose } & \multicolumn{3}{|c|}{ Protein } & \multicolumn{3}{|c|}{ Total lipids } \\
\hline & 3 days & 10 days & 45 days & 3 days & 10 days & 45 days & 3 days & 10 days & 45 days \\
\hline Control & $46.73 \pm 1.75$ & $62.06 \pm 2.56$ & $73.8 \pm 4.41$ & $39.63^{\mathrm{a}} \pm 0.994$ & $32.2^{\mathrm{a}} \pm 2.14$ & $33.63^{\mathrm{a}} \pm 1.08$ & $46.73 \pm 1.75$ & $62.06 \pm 2.56$ & $73.8 \pm 4.41$ \\
\hline Cd & $122.3^{* * *} \pm 8.71$ & $112.8^{* * * *} \pm 9.03$ & $164.86^{* * *} \pm 11.43$ & $63.82^{* *} \pm 1.23$ & $60.53^{* * *} \pm 1.93$ & $87.59^{* *} \pm 2.23$ & $122.3^{* * *} \pm 8.71$ & $112.8^{* * *} \pm 9.03$ & $164.86^{* * *} \pm 1.43$ \\
\hline Cd+0.1g EDTA/l & $78.34^{*} \pm 8.23$ & $94.9^{*} \pm 7.56$ & $157.2^{*} \pm 6.772$ & $55.31^{*} \pm 1.60$ & $54.0^{* *} \pm 1.21$ & $50.61^{*} \pm 3.91$ & $78.34^{*} \pm 8.23$ & $94.9^{*} \pm 7.56$ & $157.2^{*} \pm 6.772$ \\
\hline Cd+0.2g EDTA/l & $54.12^{\mathrm{a}} \pm 5.01$ & $66.4 \pm 5.4$ & $82.46 \pm 6.02$ & $41.63 \pm 1.75$ & $44.87 \pm 2.31$ & $38.03 \pm 1.95$ & $54.12^{\mathrm{a}} \pm 5.01$ & $66.4 \pm 5.4$ & $82.46 \pm 6.02$ \\
\hline Cd+0.3g EDTA/l & $47.75 \pm 4.71$ & $63.03 \pm 6.22$ & $74 . .1 \pm 5.68$ & $40.06 \pm 1.95$ & $34.6 \pm 0.947$ & $38.34 \pm 1.65$ & $47.75 \pm 4.71$ & $63.03 \pm 6.22$ & $74 . .1 \pm 5.68$ \\
\hline
\end{tabular}

Data are represented as means $\pm \mathrm{S} . \mathrm{E} *$ Significant at $\mathrm{P}<0.05 * *$ Significant at $\mathrm{P}<0.01 * * *$ Significant at $\mathrm{P}<0.001$

Table (6): Changes in cadmium residue in water (mgCd/L) and whole fish ( $\mathrm{mg} \mathrm{Cd} / \mathrm{g} \mathrm{dry} \mathrm{weight)} \mathrm{of} \mathrm{catfish} \mathrm{Clarias} \mathrm{garopeinus} \mathrm{exposed} \mathrm{to} \mathrm{to} \mathrm{Cd}(12 \mathrm{mg} / \mathrm{l})$ with or without EDTA.

\begin{tabular}{|c|c|c|c|c|}
\hline & \multirow{2}{*}{ Water } & \multicolumn{3}{|c|}{ Whole fish } \\
\hline & & 3 days & 10 days & 45 days \\
\hline Control & $0.06 \pm 0.03$ & $0.051 \pm 0.06$ & $0.076 \pm 0.04$ & $0.056 \pm 0.03$ \\
\hline $\mathrm{Cd}$ & $11.98 \pm 073$ & $2.93 * * * \pm 0.11$ & $4.33 * * * \pm 0.18$ & $7.2 * * * \pm 0.286$ \\
\hline $\mathrm{Cd}+0.1 \mathrm{~g}$ EDTA/1 & $7.15 \pm 0.43$ & $0.56^{* * *} \pm 0.09$ & $1.76^{* *} \pm 0.1$ & $2.96 * * * \pm 0.08$ \\
\hline $\mathrm{Cd}+0.2 \mathrm{~g} \mathrm{EDTA} / 1$ & $4.79 \pm 0.12$ & $0.25 \pm 0.07$ & $0.27 \pm 0.08$ & $1.67 * \pm 0.06$ \\
\hline $\mathrm{Cd}+0.3 \mathrm{~g}$ EDTA $/ 1$ & $2.73 \pm 0.03$ & $0.13 \pm 0.08$ & $0.17 \pm 0.06$ & $0.22 \pm 0.09$ \\
\hline
\end{tabular}




\section{استخدام الأديتا لاختزال سمية الكادميوم وتحسن التغيرات الفسيولوجية والبيوكيميائية فى (Clarin}

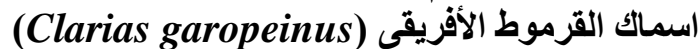

عادل محمد عيسى شلبى، ، اشرف عبد ارحمن ، مضان، مصطفى عبد المحسن الجمال، صديق ميلاد

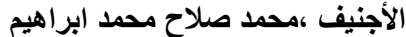

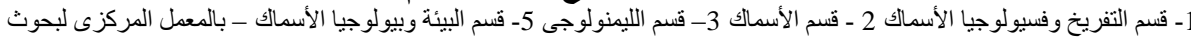

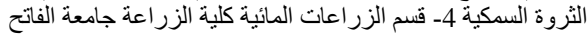

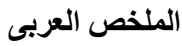

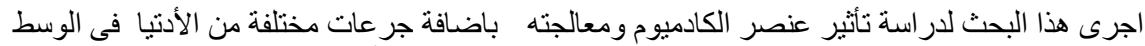

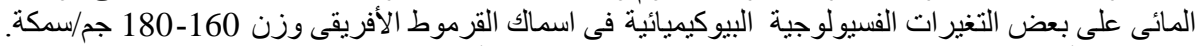

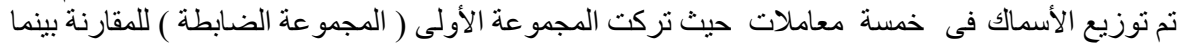

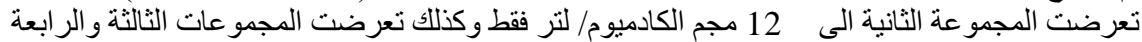

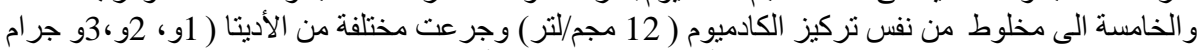

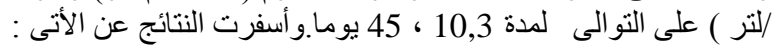

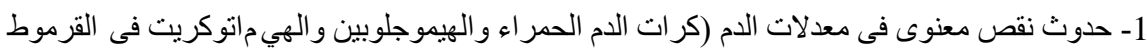

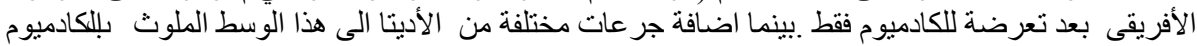

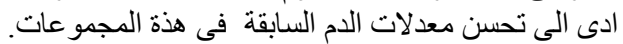

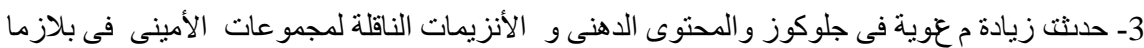

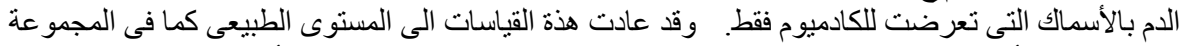

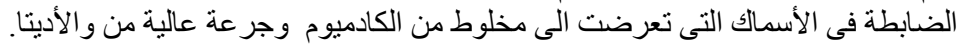

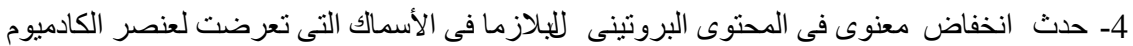

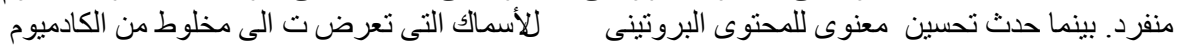
و الأديتا.

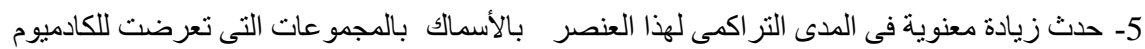

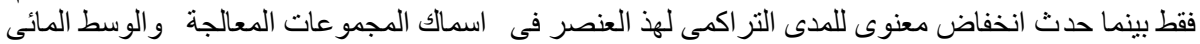

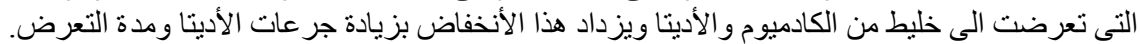

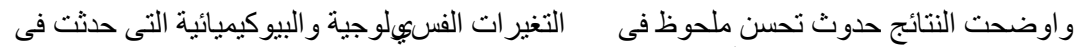

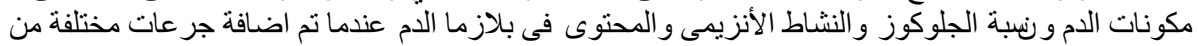

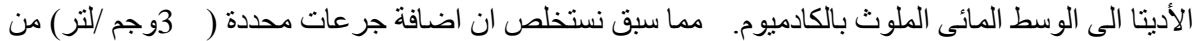

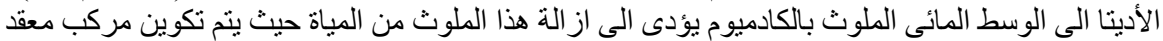

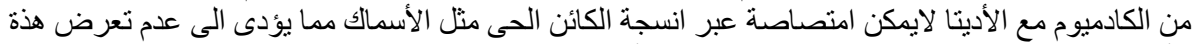

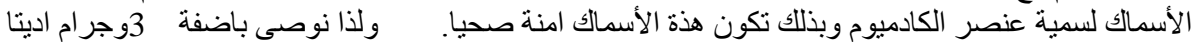

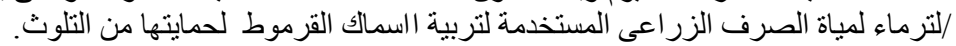

